\title{
THE PARTICIPIAL FORM AND OTHER PECULIARITIES
}

In many places in the Halakhot, Maimonides deviates from his standard formula. He neglects to declare that a given commandment is a mitsvat 'aseh and fails to produce a scriptural proof text. In some of these cases, he uses the participial form to describe the commandment, a formula such as "the Shema is recited" rather than "it is a positive commandment to recite the Shema." While the participle is a common mishnaic grammatical form, it is not one particularly well suited to articulating imperatives. ${ }^{1}$ What is the significance of this grammatical form, and why does Maimonides use it?

In an article curiously entitled "Haustafeln,"2 David Daube points out that a large majority of tannaitic rulings use this form, and suggests that perhaps it reflects the less categorical or less authoritative standing of rabbinic legislation. Daube notes that the Hebrew participle "stands for our present tense as referring to a habitual event, action or omission.... it is in this function, as an expression of the course to be taken in accordance with proper interpretation and custom, that the participle became the typically rabbinic form of legislation." He concludes: "[i]f we want to give it a name, we should call it, not imperatival participle or participial imperative, but rather advisory, didactic participle or perhaps best, participle stating the correct practice."3

1. The standard imperative form that Maimonides uses to indicate commandments is the infinitive of the verb, preceded by the preposition lamed. See, e.g., Hilkhot Hamets u-Matsah 2:1, 6:1, 7:1, and passim.

2. Daube, "Haustafeln," 295-306. The term haustafeln literally means "house panels," and it commonly refers to the domestic code of the first century C.E., as discussed in the New Testament. It centers on how the various members of the family (wife, children, slaves) were to relate to the dominating male (husband/father/master) of the household.

3. Ibid., 295-296. 
I raised this issue in chapter 6 in discussing the commandment of the priestly blessings, where Maimonides uses this odd participial form. In this chapter, I will show that the use of the participial form is more frequent than an isolated instance. I now suggest that Maimonides deliberately utilizes these participles to describe what Daube called "habitual events" or "correct practices" in places where we may have expected scriptural commandments. While not explicitly commanded by Scripture, those rituals are ancient and generally accepted, and would logically be categorized as scribal interpretations, divre sofrim, rather than as scriptural commandments.

At this point, a clarification is in order. In the next few pages, I will argue that a number of commandments that are commonly thought to be scriptural, and which the ShM deems to be scriptural, are not categorized as scriptural (de-oraita) in the Halakhot. In effect, I will ascribe to Maimonides notions that some might be inclined to label scandalous, if not downright heretical. But one need not view these notions in such an extreme fashion. I am not arguing that these commandments are not obligatory-they most clearly are. Nor do I even imply that these commandments lack scriptural force. Indeed, some of Maimonides' most prominent commentators maintain that Maimonides viewed certain divre sofrim enablements as enjoying the force of scriptural law. ${ }^{4}$ What is at issue here is not praxis but doxa, theory. Specifically, we see here how Maimonides (qua legal theorist rather than qua decisor) categorizes certain commandments that he did not find present in the plain sense of Scripture.

4. One such law categorized as divre sofrim but ostensibly enjoying the force of scriptural law is qiddushe kesef (betrothal by means of money); a marriage effected by money grants the woman the full legal status of a married woman, making her, for example, liable for the death penalty in case of adultery. See both Karo, Kesef Mishneh, and di Tolosa, Maggid Mishneh, on Hilkhot Ishut, 1:2, s.v. "u-be-ehad." Analyzing a well known responsum of Maimonides' on the legal status of qiddushe kesef, Duran interprets him as saying that anything not explicitly written in Scripture - such as qiddushe kesef- "is not scriptural but rabbinic (mi-de-rabbanan)." Duran interprets this statement as excluding hermeneutically derived laws from the enumeration of the commandments. He concludes, however, that Maimonides would certainly agree that such laws carry scriptural force. Duran, Zohar ha-Raqia, 11. Our version of the responsum does not contain the word mi-de-rabbanan and instead contrasts scriptural laws with divre sofrim laws. Responsa, ed. Blau, no. 355, 631-633. 
In chapter 7, I argued that Maimonides used the tool of peshateh di-qera to examine Scripture for commandments, interpreting the text plainly and contextually. I analyzed a few exceptional places where Maimonides deferred to traditional readings - when those readings could be said to lie within the limits of the plain sense of the text. For Maimonides, exegetical readings that deviate from context could not serve as bases for identifying scriptural commandments. In this chapter, I shall explore how the participial form functions in lieu of a declarative statement, informing us in a subtle but precise way that the specific commandment may not quite follow the canons of peshateh di-qera. This ambiguity is reinforced by the lack of a quoted proof text, effectively disconnecting the practice from the text. While most of the examples include use of the participial form, some of them reveal, if ever so subtly, an ambivalent stance through different sorts of literary artifices. These, too, we shall explore.

Following is an analysis of commandments in the Halakhot that, for the most part, use the participial form in their definition while also showing other deviations from the usual declarative introductory formula. I argue that these anomalies point to a subtle re-assignment of the commandment to another legal category, following the exigencies and implications of the peshateh di-qera hermeneutic.

\section{P10. THE RECITATION OF THE SHEMA}

In the Halakhot, Maimonides opens discussion of this commandment thus:

The Shema is recited [qorim] twice every day, once in the evening and once in the morning, as it is said: when thou sittest in thy house, and when thou walkest by the way, and when thou liest down, and when thou risest up [Deut. 6:7]. The time when people customarily lie down is evening and the time when people customarily get up is morning. (Hilkhot Qeriyat Shema 1:1)

Note, first and foremost, that Maimonides does not explicitly designate the recitation of the Shema a positive commandment, neither here nor anywhere else in this section. He does not say, "[it is a positive commandment] to read the Shema," as he does with regard to prayer, 
for example: "It is a positive commandment to pray every day" (Hilkhot Tefillah 1:1). Instead, he uses the participle qorim, idiomatically translated as "is recited" (literally, "we/you/they recite").

In the SE/ShM, the words "and thou shalt talk of them [when thou sittest in thy house, and when thou walkest by the way, and when thou liest down, and when thou risest up]" (Deut. 6:7, emphasis added) are cited as evidence for the obligation to recite the Shema. Surprisingly, this proof text is entirely omitted in the Halakhot. It appears that in the Halakhot, Maimonides is only concerned with proving that the Shema is recited twice daily—night and morning, as the expression "when thou liest down, and when thou risest up" implies — rather than proving that there exists a scriptural requirement to recite it. While such a literalist reading is plausible, it does not meet the criterion of plain sense. As Tigay observes, "these pairs of contrasting phrases are merisms. Accordingly, our verse means: speak of these words wherever you are, and at all times." What makes the metaphorical interpretation more philologically compelling is that a very similar expression is used in Proverbs 6:21-22 6 in a wisdom, non-legal, context, where the expressions "lying down" and "rising up" are clearly not intended to signify day and night. Rather, they are intended to signify continuous, round-the-clock, engagement. This may explain the reason Maimonides fails to adduce a proof text in the Halakhot for the recitation of the Shema and employs the participial form to express the obligation to recite it.

What type of obligation, then, is the recitation of the Shema? Note that the enumerative works (SE/ShM) contain one commandment to "unify Him" (le-yahado), listed as P2, and a second commandment, to recite the Shema, listed as P10, making it appear as if there are two independent scriptural commandments. A noticeably different path is taken by the Halakhot. After describing God's particular type of oneness in Hilkhot Yesode ha-Torah 1:7, Maimonides concludes: "to

5. The JPS Torah Commentary, Deut. 6:7. See also the medieval commentator Joseph Bekhor Shor, Perushe R. Yosef Bekhor Shor, ad loc.

6. Referring to "your father's commandment" and "your mother's teaching," Proverbs (6:21-22) says: "Tie them over your heart always; bind them around your throat. When you walk it will lead you; when you lie down it will watch over you; and when you are awake it will talk to you." 
know this truth is a positive commandment, as it says, Hear, O Israel: The Lord our God, the Lord is One." The formulation is as forceful as it is unequivocal; the intellectual act of cognizing God's oneness is a positive commandment. This clarity is sorely missing when it comes to the recitation of the Shema. Here, the Shema "is recited," and no proof text is offered. I submit that Maimonides no longer puts the recitation of the Shema on a par with the cognitive act, as he had ostensibly done in the ShM/SE. Instead, the recitation is simply a "correct practice," in Daube's words. This formulation places the recitation of the Shema in the category of mitsvot divre sofrim rather than in the category of mitsvot de-oraita. For the legal theorist and philosopher, the oneness of God is not something that is recited but rather something that is acknowledged and understood; it is not a formula to be recited twice a day, but rather a fundamental truth that must be assimilated and affirmed at all times.

I believe that this ambivalence with respect to the recitation of the Shema can already be detected in the ShM. The argument there, which I review immediately below, proceeds confusedly to discuss times rather than recitation and digresses unnecessarily and excessively beyond qeriyat shema. As mentioned above, Maimonides' evidence for the obligation to recite the Shema twice daily comes from the verse: "and thou shalt talk of them when thou sittest in thy house, and when thou walkest by the way, and when thou liest down, and when thou risest up." In the ShM, Maimonides adduces two rabbinic warrants, the first from BT Berakhot 21a, "where it is shown that the reading of the Shema is ordained by the Torah," and the second from T Berakhot 3:1. In context, the talmudic passage is not as definitive as Maimonides implies, for it also contains an amoraic opinion maintaining that the recitation of Shema is rabbinic. Moreover, the passage reaches no firm conclusion on this question.

The Tosefta reads: "Just as the Torah has ordained an appointed time $\left[q e v a^{\prime}\right]^{7}$ for the reading of Shema, even so have the Sages appointed a

7. Our edition of the Tosefta (ed. Zuckermandel) has here "just as an appointed time has been ordained," omitting the reference to the Torah. This omission bears on the question of whether the daily reading of Shema is a scriptural or a rabbinic precept. 
time [zeman] for prayer." 8 The ostensible value of the passage is to show by inference that appointing times for reading Shema is a scriptural requirement, while appointing times for other prayers is a rabbinic ordinance. Oddly, Maimonides does not make this inference explicit; instead, he proceeds to discuss prayer in more general terms. In effect, he uses this warrant to show that it is the rabbis who appointed times for prayers, although the activity of prayer itself is scripturally prescribed. This distinction appears unnecessary, since Maimonides already explained in P5 that prayer is scripturally mandated. It is surprising that Maimonides does not use this text to emphasize the scriptural character of the recitation of the Shema, perhaps implying that while he accepted the second half of the dictum (that times for prayer are rabbinically ordained), he was not convinced of the first (that times for the Shema are biblically ordained). He may have, for example, thought it possible to read the Tosefta passage as indicating that the Torah merely hinted at the appropriate times for the Shema-thus reading the verse as an asmakhta rather than as a genuine proof. As I have noted on a number of previous occasions, asmakhtot are not valid hermeneutics on which to base scriptural claims. By way of contrast, the Tosefta suggests that when it came to appointing times for prayers, the Rabbis were left to their own ingenuity.

This interpretation dovetails well with what appears to be another seemingly redundant statement immediately following Maimonides' interpretation of the second half of the dictum:

This is what the Sages mean when they say: "[The Men of the Great Assembly] appointed prayers to correspond with the daily burnt offerings"; that is to say, they fixed the times of prayer to correspond with the times at which [the daily burnt offerings] were brought.

Note that in this text, the term qeva' is set in apposition to zeman (time), perhaps bearing the meaning of "fixed form" rather than "appointed time." The phrase could thus mean that just as the Torah has set a fixed form, the Shema, for the affirmation of God's unity, so too have the Sages appointed a time for prayer. But see following note.

8. The Zuckermandel edition of the Tosefta has the word zeman here. However, the Tosefta appended to the standard editions of the Babylonian Talmud uses the term qeva' again instead of zeman. See Sefer ha-Mitsvot, ed. Heller, ad loc., n. 22. 
Consistent with the above thesis, Maimonides explains that the Rabbis appointed times for prayers to correspond with the daily burnt offerings. This was an entirely original contribution and one that, unlike the asmakhta of the Shema, could not be traced to an allusion in the text. The Tosefta thus offers a comparison and a contrast. While both the recitation of the Shema and daily prayers are rabbinic commandments, the former is based on an asmakhta and the latter is based on a reasoned argument. In short, this rambling presentation gives us a window onto Maimonides' own doubts with respect to the legal status of the Shema recitation.

The use of the participial form in the Halakhot may reflect Maimonides' continued ambivalence regarding the scriptural status of this commandment. Alternatively, it may reflect a fully settled position that qeriyat shema is not a mitsvat 'aseh but simply a divre sofrim obligation. Regardless of how one understands the obligation, no change in praxis is implied. Towards the end of this chapter, I will attempt to demonstrate that there is indeed a difference between the views that qeriyat shema is de-oraita or mi-divre sofrim even according to those jurists who saw the latter as enjoying scriptural force.

\section{P11. TO LEARN TORAH AND TO TEACH IT}

What is noteworthy about the presentation of this commandment is not that it uses the participial form, which it does not, but rather that it lacks the typical declarative statement that accompanies positive commandments. In its place we find the following roundabout and atypically worded introduction:

Women and slaves are exempt from the obligation of studying Torah. But a father is obligated [aviv hayav le-lamdo] to teach his young son Torah, as it is said, And ye shall teach them to your children, talking of them (Deut. 11:19). (Hilkhot Talmud Torah 1:1)

Maimonides begins by identifying everyone who is exempt from the obligation to study Torah, and then goes on to list those who are obligated to teach Torah and to whom: father to son, grandfather to 
grandson and, lastly, teacher to disciples. Notably, neither teaching nor studying Torah is ever designated as a positive commandment. ${ }^{9}$ Note, too, that to convey the sense of obligation, Maimonides chooses the term hayav, a commonly used rabbinic expression, instead of a verbal form of mitsvah, the scriptural designation for obligation.

Finally, it should be noted that the introductory section only discusses teaching Torah-to one's children, one's grandchildren and one's disciples - and supports this obligation with Torah passages. No mention is made of the obligation to study Torah until halakhah 8 , where it is supported by a non-Torah passage: "But thou shalt meditate therein day and night" (Josh. 1:8). ${ }^{10}$ By way of contrast, in the enumerative works, both obligations are derived from the same proof text: "and ye shall teach them to your children, talking of them" (Deut. 11:19). ${ }^{11}$

All the peculiar features noted above suggest that in the Halakhot, Maimonides does not subscribe to the idea that there is a scriptural basis for the commandments to study and teach Torah. And I would submit that the peshateh di-qera supports this thesis. Indeed, the context of Deuteronomy 11:19, urging one to teach one's children, does not appear to refer to the study of Torah, but rather to the proclamation of God's unity and to the love that we must show for Him (vv. 5-6).

Further support for this conjecture can be found in a statement that Maimonides makes in Hilkhot Qeriyat Shema. After ruling that one must recite the Shema twice each day, Maimonides explains why one recites the passage beginning "Hear O Israel" (Deut. 6:4-9) before those beginning

9. The failure to make a declaratory statement and the peculiar and absolutely atypical opening prompts the commentator $\mathrm{RaDBaZ}$ to offer a justification: Maimonides wanted to emphasize the fact that women and slaves are exempt from the obligation even though they are generally obligated to perform all positive commandments that have a fixed time. In any case, one can see that Maimonides succeeded in diverting attention from the critical issue, namely, that he has not designated the study and teaching of Torah as a positive commandment. See RaDBaZ, Sheelot u-Teshuvot haRaDBaZ, vol. 8, siman 1 .

10. By definition, prophetic passages cannot serve as valid proof texts for scriptural commandments.

11. The Sifre comments that the Hebrew word ve-shinantam, here translated as "you shall teach them," can also be understood as coming from the piel form of the verb shinen, "sharp." The words of Torah shall be "sharp" in the mouth of the teacher, a fluency that implies prior study and familiarity. 
"And it shall come to pass" (Deut. 11:13-21) and "The Lord spoke" (Num. 15:37-41). He writes: "The section beginning Hear O Israel is recited first, because it contains the unity of God, the [duty to] love Him [ve-ahavato] and [the duty to teach about] Him [ve-talmudo], because this is the great principle on which everything depends." 12 As Maimonides details elsewhere, Scripture commands the believer to cognize intellectually God's oneness (P2; Hilkhot Yesode ha-Torah 1:7). Therefore, one may conclude that the passage "and thou shalt teach them diligently unto thy children" exhorts one to impart this knowledge to others.

Maimonides may have viewed the commandments to study and teach Torah as merely a rabbinic appropriation of scriptural advice, a classic example of divre sofrim..$^{13}$ At least to Maimonides' way of thinking, this appropriation may have been justified by practical considerations: only the study of the Law can lead to the proper performance of commandments. ${ }^{14}$ As we saw, the introductory presentations of each of the commandments in the Halakhot contain a great deal of information about Maimonides' legal philosophy and classification. Given the revered standing that the study of Torah enjoyed among rabbinic students and the general public, it is not surprising that Maimonides came to use subtle literary devices, such as formulaic variants, to hide his true opinion.

\section{P12, P13. TO BIND PHYLACTERIES ON THE HEAD AND ON THE ARM}

Maimonides opens Hilkhot Tefillin in the following manner:

12. My translation. I take ahavato and talmudo as referring to God, while the words "because this is the great principle" (ki hu ha-iqqar ha-gadol), refer back to God's unity. Hyamson translates the phrase as "studying His words," an interpretative statement that follows the approach of most rabbinic commentators.

13. In Hilkhot Talmud Torah 1:2, Maimonides states: "on traditional authority (mi-pi hashemu'ah lamdu), the term 'thy children' includes disciples." This tradition does not say that one ought to teach one's children Torah; it simply says that Scripture uses the word "children" to include disciples.

14. See Hilkhot Talmud Torah 1:3 on the importance of study for the performance of commandments. Alternatively, the study of the Law settles a person's mind (meyashvim da'atam shel adam tehillah) and allows him to embark on the true goal of the scriptural commandment: metaphysical contemplation. See Hilkhot Yesode ha-Torah 4:13. 
The following four passages... are the ones that are written by themselves [or "individually," bi-fne 'atsmam]; they are wrapped in leather and are called tefillin. They are to be placed [u-manihin otam] on the head and they are tied [ve-qoshrin otam] on the arm. ${ }^{15}$ (Hilkhot Tefillin 1:1)

Because tefillin are not explicitly defined (or mentioned by that name) in Scripture, ${ }^{16}$ Maimonides logically chooses to describe the objects with which one is to perform the commandment before he declares and explains the nature of the commandment. It is only immediately after this description that the difficulties become apparent: "They are to be placed [u-manihin otam] on the head and they are tied [ve-qoshrin otam] on the arm." Why does Maimonides use the participial form, rather than declaring clearly and unequivocally that it is a positive commandment to place these tefillin on the head and tie them on the arm? And why does he fail to support this practice with the appropriate scriptural citation, as he did in the SE/ShM-and as he does in the presentation of nearly every commandment?

Similarly, in Hilkhot Tefillin 4:1-2, Maimonides discusses the exact spot on which one should place these tefillin. Yet he not only omits the scriptural verse that supports this identification, but he adds: "We learned the positioning of the tefillin on the arm and on the head from the oral tradition [mi-pi ha-shemu'ah lamdu]." His resorting to tradition for this point implies that he does not think that the scriptural verse "And thou shalt bind them for a sign upon thy hand and they shall be for frontlets between thy eyes" is sufficiently revealing. Moreover, as discussed in chapter 7, the expression mi-pi ha-shemu'ah without an accompanying proof text generally signifies that we are in the presence of an ancient tradition rather than a scriptural law. Lastly, nowhere does Maimonides

15. In the continuation, Maimonides states further that "according to the Torah, a mistake in the tip of only one of the letters in the four passages renders the whole unfit; they must be written perfectly as they are supposed to be." He then rules that the same is true for passages written for the mezuzah and for the Torah scroll. These are laws that pertain to scribing any passages or sections of the Torah; they do not confer a scriptural status on the commandments of placing tefillin on the head and arm and mezuzot on doorposts.

16. "And thou shalt bind them for a sign upon thy hand, and they shall be for frontlets between thy eyes" (Deut. 6:8). 
cite the midrashic play on the scriptural word totafot used to substantiate the idea that the phylacteries contain four passages. ${ }^{17}$ The impression we get is that Maimonides was both troubled by the correspondence between the praxis and the plain meaning of the commands to place a "sign" (ot) and a "remembrance" (zikaron/totafot) ${ }^{18}$ on one's arm and head and by the philological genuineness of the midrash on the word totafot. ${ }^{19}$

Throughout history, several interpreters have suggested that these verses should be understood in a metaphoric sense. Aqila, Theodotion, and some manuscripts of the Septuagint read the verses as exhorting one to be aware constantly of God's teachings. In the Middle Ages, the Karaites also stressed the metaphoric view. In his long commentary to Exodus 13:9, Ibn Ezra, repeating the familiar refrain ein miqra yotse miyede peshuto ("a scriptural verse never loses its peshat sense") rejects the metaphoric views of totafot offered by the Karaites because the literal interpretation is plausible in context. ${ }^{20}$ By even citing and engaging such a view, he seems to show a certain degree of sympathy for the figurative interpretation. RaSHBaM also writes that according to the "depth of the plain interpretation" (omeq peshuto), these words should be taken metaphorically. ${ }^{21}$ These disagreements among Maimonides' predecessors and contemporaries highlight the exegetical difficulties encountered with Deuteronomy 6:8 and the so-called commandment

17. Cf. RaSHI on Deut. 6:8, based on BT Sanhedrin $4 \mathrm{~b}$.

18. Zikaron in Exod. 13:9; totafot in Exod. 13:16, Deut. 6:8, 11:18.

19. Cf. BT Menahot 34b. R. Ishmael and R. Aqiba both parse the tris legomenon "totafot" to signal the quantity four, referring to the four sections inscribed on the parchments, but without explicating the term. The far-fetched etymological explanations in the Talmud all imply that totafot is only an allusion (remez) to tefillin, which is another way of saying that tefillin are not explicitly discussed in Scripture. Accordingly, at least part of the commandment of tefillin should be seen as mi-divre sofrim, like all precepts informed by tradition and only tenuously linked to the text. See chapter 7, note 10 above.

20. After equating peshat with literalism, Ibn Ezra says that one should be willing to accept literalism as long as it makes good sense. Interestingly, he rejects a philological interpretation based on the way similar expressions are used in Proverbs (1:9, 6:21), because Proverbs, unlike the Torah, is a book of parables. Clearly, his appreciation of peshat is quite different than the one I ascribe to Maimonides, as is his belief that the Torah contains no parables. In his short commentary, Ibn Ezra also offers the metaphoric interpretation-before going on to reject it-but does not ascribe it to the Karaites.

21. RaSHBaM, Perush ha-Torah on Deut. 13:9. See The JPS Torah Commentary, Deuteronomy, Excursus 11. 
of tefillin. The view that the commandment of tefillin is not a mitsvah de-oraita would have surely shocked the Jewish community. The use of the participial hid this opinion from the masses by simply not having to state explicitly that the obligation to wear them is mi-divre sofrim. It is also possible, however, that the participial form may have genuinely expressed a more ambivalent stand on the matter.

\section{P15. TO AFFIX A MEZUZAH}

Much of what was said about tefillin can be said about the commandment to affix a mezuzah. Maimonides opens Hilkhot Mezuzah (Hilkhot Tefillin u-Mezuzah ve-Sefer Torah 5:1) by describing the mezuzah and the process of its production: "How is the mezuzah to be written [ketsad kotvin, lit., "how do they write the mezuzah"]? One writes two passages ... in a single column on a piece of parchment."22 Most of the first chapter is devoted to explaining how to write the mezuzah. In 5:10, Maimonides rules that "all are obligated [ha-kol hayavin] to affix mezuzot, even women and slaves," without designating this obligation a positive commandment. Instead, we note here too, as with the study of Torah, the use of the common rabbinic term for obligation, hayav (here hayavin). Maimonides misses the last opportunity to designate the writing and placing of a mezuzah as a positive commandment in 6:12, when he explains where the mezuzah is to be affixed. Once again, he makes use of the participial form: "Where is the mezuzah to be affixed [ve-hekhan qovin et ha-mezuzah]?" Furthermore, nowhere in Hilkhot Mezuzah does Maimonides cite the traditional evidence for this commandment claim, as he did in the enumerative works: "And thou shalt write them upon the doorposts of thy house, and upon thy gates" (Deut. 6:9). ${ }^{23}$

I suggest that, here again, Maimonides reads the scriptural pericope in a manner consistent with the context, in this case giving

22. Note that the verse speaks about writing the words "upon the doorposts of thy house," and that it is only via an inference from similar words (gezerah shavah) that the rabbis interpreted the passage to say that the pentateuchal sections should be written on parchment. See BT Menaḩot 34a. As we saw earlier, Maimonides deems derivations using hermeneutic rules like gezerah shavah to be mi-divre sofrim.

23. He does cite part of this verse in connection with a detail of the law: "Granaries, barns, lumber rooms, and storehouses are exempt from mezuzah, since it says, of thy house [Deut. 6:9]." 
it a figurative meaning. Since the subject of the larger passage is God's unity, this knowledge is what should always envelop each person; the doorposts are as much a sign of constancy, immediacy and nearness as one's forehead and arms. ${ }^{24}$ Maimonides' formulaic deviation, the lack of a declaratory statement ${ }^{25}$ and the failure to adduce textual evidence for the commandment to write or affix a mezuzah, as well as his use of the participial form and the rabbinic term for obligation, suggest, at the very least, an extraordinary ambivalence about the scriptural status of this commandment. I posit that Maimonides' exegetical sense would not allow him to accept the Sages' traditional reading of Deuteronomy 6:4-9, a passage that contains the fundaments of the religion. Through various literary means and through the use of the participial form, Maimonides either hinted that the commandment to affix a mezuzah is a mitsvah mi-divre sofrim or simply expressed doubt regarding the scriptural status of the commandment. Regardless, there would be no impact on praxis; Maimonides made sure to uphold every detail of the traditional rabbinic interpretation when explicating the practice in the Halakhot.

\section{P17/P18. THAT THE KING SHALL WRITE A SCROLL OF THE TORAH FOR HIMSELF (P18 IN THE SE AND P17 IN THE SHM ENUMERATION)}

While the command that the king shall write a scroll of the Torah for himself has a scriptural basis, Maimonides does not designate it as a

24. Maimonides does not approve of the objectification of the "great duty" to affirm God's unity, love, and worship. The commandment of belief is condensed into an object that could become an amulet for personal interests, in the hands of fools. Writing about those who inscribe the mezuzah with the names of angels, holy names, or other such protective mantras, Maimonides says: "For these fools not only fail to fulfill the duty [bittlu ha-mitsvah] but made a great duty [mitsvah gedolah], namely the unity of the Name of God, His love and His worship, as it were an amulet to promote their own personal interests" (Hilkhot Mezuzah 5:4). Note the expression bittlu ha-mitsvah instead of the phrase that one might expect, bittlu mitsvat 'aseh.

25. Maimonides also fails to designate the commandment as a mitsvat 'aseh in the rest of Hilkhot Mezuzah, even when he points out how one is liable if one fails to fulfill the command. We note that at 5:4, he uses the expression bittlu ha-mitsvah instead of the expected bittlu mitsvat 'aseh. See the note 24 above. 
positive commandment in the Halakhot. ${ }^{26}$ Oddly enough, although Maimonides discusses the king's obligation to write a sefer torah in two separate places, Hilkhot Sefer Torah (7:2) and Hilkhot Melakhim (3:1), the obligation is listed only under the Headings to Hilkhot Sefer Torah and not under the Headings to Hilkhot Melakhim.

The two formulations are substantively similar, with one exception: in Hilkhot Sefer Torah, Maimonides writes: "The king is obligated [metsuveh] ${ }^{27}$ to write one scroll of Law for himself, for the sake of the king, an additional scroll to the one he had while still a commoner" [emphasis added]. Maimonides here refers to the commandment that everyone is obligated to write a scroll of the Torah (P17). In Hilkhot Melakhim, on the other hand, Maimonides writes that "the king writes for himself a scroll of Law in addition to the scroll that his forefathers had left him" [emphasis added]. This is based on a baraita quoted in BT Sanhedrin 21b: "And he must not take credit [lit. "adorn himself"] for the one belonging to his ancestors." A few sentences later, Maimonides acknowledges the obligation on each person to write a scroll of the Torah, when he says that "one [of the scrolls], the writing of which is obligatory upon every Jew, he places in his treasure-house." 28 In neither of these sections, however, does Maimonides designate this royal obligation a positive commandment, despite the clear proof text: "And it shall be, when he sitteth upon the throne of the kingdom, that he shall write him a copy of this law in a book, out of which is before the priests the Levites" (Deut. 17:18).

I argue here that Maimonides' failure to declare a positive commandment is supported by a peshateh di-qera reading of the scriptural passage. The idea that the king must write two scrolls of law, one as a commoner and one as a king, comes from reading mishneh as "double" and then abstracting the phrase from its context, so it is interpreted that he must write to himself a double torah, that is, two torot. ${ }^{29}$ Taking the context into account, however, the plain sense of

26. Not so with regard to the average man's obligation to write a sefer torah. There he clearly states that it is a positive commandment to write one. See Hilkhot Sefer Torah 7:1.

27. See RaMBaM Meduyaq, ed. Shailat, Hilkhot Sefer Torah 7:2, n. 7.

28. The phrase used is "bet genazav." Compare Ezra 5:17; 6:1.

29. The talmudic exegesis (BT Sanhedrin 21b), "he writes for his own sake [lishmo] two torot" likely means that he writes two scrolls when he accedes to the throne, not that 
the text calls for a different reading; namely, the king must write a double, i.e., a copy, of this torah, which is in the hands of the Levites ("from in front of the Levite priests). In the Halakhot, Maimonides renders "mishneh" in a manner to reflect this plain sense (and as the targumic interpreter did), specifically, a copy of the Torah.

The king must copy for himself the Torah (probably working from the one lodged in the Temple), which he shall keep about him at all times. It does not mean that he has to write for himself a second scroll. ${ }^{30}$ Thus the king is only obligated to write one scroll of the Torah, the same obligation incumbent on every Jew. Furthermore, the requirement that the king store one scroll in his treasure house is rabbinic: Scripture refers only to the one he must write, saying, "and it shall be with him, and he shall read therein all the days of his life" (Deut. 17:19). Yet, to uphold an ancient tradition that the king must place a scroll in his treasure house, Maimonides has the king write an extra scroll of law while placing the one that he wrote as a commoner in the treasure-house ("one, the writing of which is obligatory upon every Jew, he places in his treasure house"). ${ }^{31}$ Thus all of the regulations requiring a king to write a second scroll are rabbinic, not scriptural.

To reiterate: the Halakhot adopts the plain sense of the verse that the king must write one copy of the Torah for himself-the very same obligation incumbent upon every commoner, as stated in Hilkhot Sefer Torah 7:1. In light of this, it is the king's obligation to write a scroll of the law is not a separate positive commandment. This also explains why Maimonides officially positioned this detail of the commandment in Hilkhot Sefer Torah, rather than in Hilkhot

he writes one upon accession to complement a previously inherited scroll. See PhM, M Sanhedrin 2:5. Note that this reading differs from the ones presented in the Halakhot and would constitute a third position.

30. See Onqelos, ad loc.

31. Karo (Kesef Mishneh, Hilkhot Melakhim 3:1) correctly sensed that Maimonides obligates the king to write only one scroll, noting that this contradicts the plain sense of the passage in BT Sanhedrin 21b. Karo acknowledged that his attempt to reconcile Maimonides' ruling with the passage is forced. According to my interpretation, Maimonides' philological understanding of the term mishneh does indeed reject the talmudic passage; even this one extra scroll is a concession to a rabbinic ordinance. 
Melakhim: ${ }^{32}$ the commandment to the king is only a detail of the general commandment that every Jew must write a scroll of law. Maimonides labels the general commandment a mitsvat 'aseh, but omits such a designation for the command that the king write a scroll of law, since, from a scriptural point of view, no such special commandment exists. ${ }^{33}$

\section{P127-P130. TO SET ASIDE VARIOUS TITHES}

As interpreted by the Oral Law, Leviticus 27, Numbers 18, and Deuteronomy 14 describe the tithes that were incumbent on the Israelites upon entering the Land of Israel, three of which were to rest on the Israelites and the fourth on the Levites. The first tithe was to be given to the Levites, and the oral law stipulates that everything growing from the land would be subject to the tithe. The second tithe prescribed by Scripture was to be consumed by the owner in Jerusalem, while a third tithe would be levied for the benefit of the poor. In the Halakhot, Maimonides fails to designate any of these tithes as positive commandments. Additionally, he makes heavy use of the participial form -in this case, the terms "mafrish" and "mafrishin," from the root "to set aside" or "to separate" - throughout his discussion of the tithes, both in Hilkhot Matnot 'Aniyim and Hilkhot Ma'aser.

Maimonides introduces the first tithe (ma'aser rishon) in the following manner: "After one has set aside the great heave offering [terumah gedolah], he sets aside [mafrish] one-tenth of what is left. This is what is called first tithe" (Hilkhot Ma'aser 1:1). Contrast this with the way he presents the commandment (P126 in the ShM) to separate the great heave offering (terumah gedolah) for the priest: "All human food

32. One might well ask: according to Maimonides, what is the novelty of the king's command? I suggest that the novelty lies in the king's obligation to carry the scroll with him wherever he goes, reading from it all the days of his life, as per the proof text: "And it shall be with him, and he shall read therein all the days of his life" (Deut. 17:19), an obligation not required of a commoner.

33. From a hermeneutic point of view, however, the commandment that the king must write a scroll for himself provides the basis for the general commandment that every Jew must write his own scroll. This is the reason that the ShM enumerated the king's commandment before the general one, following BT Sanhedrin 21b. See the earlier discussion of P17 in chapter 5 , note 52. 
that is watched over and that grows out of the soil is subject to the heave offering. It is a positive commandment to separate from it the first fruits for the priest" (Hilkhot Terumot 2:1).

The second tithe (ma'aser sheni) follows the form of the first:

After the first tithe has been set aside each year, one must set aside [mafrishin] also the second tithe ... In the third and sixth years of each septennate, the poor man's tithe [ma'aser 'ani] must be set aside [mafrishin] instead of the second tithe as we have explained. (Hilkhot Ma'aser Sheni 1:1)

The briefly-mentioned third tithe, ma'aser 'ani, is described in greater detail in the sixth chapter of Hilkhot Matnot 'Aniyim, which also details five types of gifts that one gives to the poor from the produce of the land: peah (lit., "corner of the field"), gleanings of grapes, gleanings of olives, the forgotten sheaf, and the defective grape clusters. Ma'aser 'ani is introduced there as "a sixth gift." The fourth tithe, incumbent on the Levites and given to the priest (terumat ma'aser), is discussed in Hilkhot Terumot (3:12) because of its affinity to the great heave offering. ${ }^{34}$ Maimonides refers to this requirement as mitsvat terumat ma'aser, though he still fails to designate it a mitsvat 'aseh. ${ }^{35}$

I have not yet found a totally satisfactory solution to this unusual presentation. Perla offers a promising approach, observing that scriptural evidence for the obligatory nature of the tithe commandments is ambiguous. He suggests that the exegeses underpinning the tithe of cattle (which I have not analyzed here), the first tithe, and the poor man's tithe are merely asmakhta be-alma and derashot be-alma, ${ }^{36}$

34. Since this tithe is particular to the Levites, it does not form part of the ordinary order of tithes.

35. The expression mitsvat terumat ma'aser should be rendered as "the proper way to perform terumat ma'aser" and it is used deliberately as a contrast with a second and less desirable way to fulfill this requirement. The halakhah reads as follows: "The commandment of heave offering of the tithe applies to the Levite, who must set it aside out of his tithe.... An Israelite, however, may set it aside and give it to the priest, and then give the balance of the tithe to the Levite, after he has set aside the latter's heave offering, which is the tithe from the tithe" (Hilkhot Terumot 3:12).

36. In these formulations, be-alma means "merely" or "only," and the expressions may be translated as "merely an asmakhta" and "merely a derashah." These creative exegeses 
rabbinic ordinances supported by scriptural verses. As a result, Perla argues that Sa'adiah was correct to list these three tithes in the indicative rather than the imperative mode. ${ }^{37}$ Through a peshateh diqera lens, one could argue that these tithing commandments, or at least some of them, could be classified as mitsvot mi-divre sofrim, thus justifying Maimonides' use of the participial form when describing these commandments.

Scripture's indeterminacy may even extend to the second tithe. In the ShM, Maimonides quotes the Sifre, which, commenting on the words "Thou shalt surely tithe all the increase of thy seed" (Deut. 14:22) writes: "I would only know this about the second tithe, regarding which Scripture speaks" (emphasis added). ${ }^{38}$ This comment helps Maimonides prove that the second tithe represents a scriptural obligation. Maimonides' reliance on the oral tradition is confirmed in the SE: "To set apart the second tithe to be eaten by its owner in Jerusalem, as it is said, Thou shalt surely tithe [Deut. 14:22]. They learnt from tradition [mi-pi ha-shemu'ah lamdu] that this refers to the second tithe." This is one of the five instances occurring in the SE (noted earlier in chapter 7) in which Maimonides resorts to the oral tradition rather than relying directly on the text to substantiate a commandment claim. Yet, it appears that he harbored some doubts after all with respect to this reading, because he does not cite it in the Halakhot. While reversals from previously held opinions are not rare in Maimonides' works, I could find no other instance in the Halakhot in which Maimonides fails to make use of a traditional reading on which he had previously depended for the elucidation of the same scriptural proof text. ${ }^{39}$ Perhaps by the

do not represent veritable sources of the law; rather, they constitute supports or mnemonics for an existing law that was already known from tradition.

37. Perla, Sefer ha-Mitsvot le-RaSaG, vol. 1, 612b-c. With respect to at least one of these three tithes, the tithe of cattle, we find that Maimonides upholds the scriptural basis of the commandment and designates it as such.

38. Sifre Deuteronomy 105 (164). For an explanation of the rabbinic exegesis that underpins this tradition, see Epstein, Torah Temimah, Deut. 14:22, n. 38. Ibn Ezra, Deut. 14:28, s. v. "miqtseh," cites an opinion of the "heretics" (i.e., Karaites), stating that the passage commencing with "Thou shalt surely tithe" refers to the first tithe, not the second. Does he believe that their interpretation is plausible according to the peshat?

See the discussion of "mi-pi ha-shemu'ah lamdu" in chapter 7. 
time he wrote the Halakhot, Maimonides had come to question the authoritativeness of the tradition, which in turn forced him to change his opinion about the scriptural status of the second tithe.

There is even some evidence that Maimonides equivocated regarding the exegetical basis for the first and second tithes. In the various versions of the $S h M$, we find three separate probatory texts substantiating the first tithe (P127): two of the explanations use their own proof texts, while a third one conflates both proof texts. ${ }^{40}$ Contrary to Maimonides' assertion, the Leviticus 27:30 proof text used in one version is contradicted by rabbinic opinion, which maintains that it refers to the second tithe, rather than to the first. ${ }^{41}$ This or perhaps some other reason may have led Maimonides to offer a second proof text, found in a second version preserved by one of the Arabic manuscripts: "For the tithe of the children of Israel, which they set apart as a gift unto the Lord" (Num. 18:24). The Numbers proof text does not denote an obligation, however, nor can it easily be identified with the first tithe (ma'aser rishon) of the tithing cycle. ${ }^{42}$

In sum, the participial form may well reflect Maimonides' ambivalent stance on the scriptural status of tithes, a stance that can be attributed to the lack of exegetical clarity found in talmudic and midrashic sources. It is also possible that Maimonides had not been ambivalent after all, and the use of the participial may reflect a view that tithing laws represent only correct practices — and therefore ought to be categorized as mitsvot mi-divre sofrim and not as mitsvot de-oraita.

40. In the Arabic manuscript (and in the Halakhot), Maimonides quotes the verse "for it is the tithes set aside by the Israelites as a gift to the Lord [that I give to the Levites as their share]" (Num. 18:24) to indicate "that this tithe belongs to the Levites." In Nahmanides' version of the ShM, Ibn Ayub's translation, and the SE, however, Maimonides instead quotes the verse "And all the tithe of the land, whether of the seed of the land or of the fruit of the tree [shall be the Lord's]" (Lev. 27:30). MnT's translation presents both proof texts, conflating the two versions. It is reasonable to conclude that the Numbers 18:24 proof text forms part of the latest version, since it is the proof text ultimately quoted in the Halakhot.

41. See RaSHI's commentary to the Pentateuch, ad loc.; Nahmanides, Hasagot to Rule 12, 190.

42. Cf. Sefer ha-Mitsvot, ed. Heller, ad loc., n. 5, who alerts the reader to the textual confusion. See also Henshke, "Le-Toldot Parshanutan shel Parashiyyot Ma'aser," 97101, who arrives at a similar conclusion. 


\section{P168. TO DWELL IN BOOTHS SEVEN DAYS}

The presentation of this commandment in the Halakhot exhibits a number of peculiar elements. First, the chapter that discusses the duty to dwell in a booth (sukkah), chapter 6 of Hilkhot Sukkah, begins by listing those who are exempted from dwelling in the booth- "women, slaves, and minors" - rather than declaring that there is a positive commandment for men to dwell in a sukkah. Note that the form of this opening presentation parallels almost exactly the one used in Hilkhot Talmud Torah for the commandment to study and teach Torah. In my discussion of that commandment, I demonstrated that, at a minimum, Maimonides was ambivalent about its scriptural status. Accordingly, this presentation might suggest a similar concern.

Additional peculiarities may be cited. The proof text does not appear until halakhah 5, and then only to describe the manner in which the duty should be performed - not to substantiate the basic obligation to dwell in booths during those seven days:

How is the commandment to dwell in a booth [mitsvat ha-yeshivah basukkah] to be observed? One should eat, drink, and reside in the booth day and night throughout the whole of the seven days of the festival, exactly as one resides in his house during the rest of the year. During these seven days one should regard his house as a temporary home and the booth as his permanent home, in accordance with the verse, Ye shall dwell [teshvu, lit., "sit"] in booths seven days [Lev. 23:42].

The imperative form is notably absent from halakhah 6, and in its stead, the participial is used heavily: "Both by day and by night, one eats, drinks and sleeps [okhlin ve-shotin ve-yeshenim, lit., "they are eating, drinking, and sleeping"] in the booth throughout the whole of the seven days." Finally, in halakhah 7, when Maimonides at last declares that there is an obligation to eat in the sukkah on the first night of the festival, he states:

It is obligatory [hovah] to eat in the booth on the first night of the festival. Even if one eats as little as an olive's bulk of bread, he has fulfilled his duty. Thereafter the matter is optional: If one wishes to eat a regular 
meal, he must eat it in the booth, but if he prefers to eat only fruit or parched ears outside of the booth during the remainder of the seven days he may do so. This is thus analogous to the law concerning the eating of unleavened bread during Passover.

For "obligation," Maimonides uses the rabbinic term hovah, not the expected phrase mitsvat 'aseh. Contrast this formulation with the way he describes the obligation to observe the Passover festival: "It is a positive commandment from the Torah to eat unleavened bread on the night of the fifteenth of Nissan, as it says, At even ye shall eat unleavened bread [Exod. 12:18]."

These general literary considerations suggest that Maimonides may have viewed the commandment to dwell in a sukkah as non-scriptural. Moreover, Maimonides' use of the more neutral participial form that I hypothesize indicates correct practices, strengthens my suspicion that he categorizes this commandment as a mitsvah mi-divre sofrim. I suggest that the rituals of Sukkot are not based in scriptural law-they appear to be purely a construct of the oral law. My demonstration rests on three separate but complementary arguments: the historical analogue; the hovah, or obligation to eat in the sukkah the first night of the festival; and the laws of the sukkah.

\section{The historical analogue}

Scripture declares: "Ye shall dwell in sukkot seven days.... that your generation may know that I made the children of Israel to dwell in sukkot, when I brought them out of the land of Egypt" (Lev. 23:42-43).

Despite this explanation, the scriptural narrative of the Israelites does not recount their dwelling in sukkot anytime during their journey in the wilderness. What, then, were these sukkot in which "the children of Israel dwelt when they were brought out of Egypt"? Tannaim are divided on this question. R. Eliezer ${ }^{43}$ maintains that sukkot were booths,

43. Based on Sifra Emor 17:11 (103b). The printed editions of the Babylonian Talmud, BT Sukkah 11b, reverse the attributions. Jeffrey L. Rubenstein offers persuasive arguments for considering the Sifra's version of the attributions to be the more reliable one. See Rubenstein, The History of Sukkot in the Second Temple and Rabbinic 
dwellings used by the sojourners to protect them from the inhospitable desert climate. R. Akiva maintains that the word "sukkot" alludes to the "clouds of the glory" (anane ha-kavod) that surrounded the Israelites during their travels through the desert, providing them with multiple types of protection, including shade against the searing sun. If, as is the norm in legal matters, one follows R. Akiva's opinion, then the word "sukkot" refers to heavenly clouds rather than manmade booths. We might then wish to interpret the injunction "Ye shall dwell in sukkot seven days" figuratively: you shall live under My protection for seven days, as you did in the days of old. We are left with the question: how does one live under God's protection for seven days? It would appear then that only the oral law can resolve this question.

\section{The hovah or obligation to eat in a sukkah the first night of the festival}

The practice of eating the minimum equivalent of an olive's bulk of bread in a sukkah on the night of the fifteenth of Tishre appears to be a mitsvah mi-divre sofrim and not a mitsvah de-oraita. While eating unleavened bread on the night of the fifteenth of Nissan is scripturally prescribed, the Torah does not mention eating in the sukkah on the night of the fifteenth day of Tishre. The talmudic sages (BT Sukkah 27a) derive this obligation through a gezerah shavah, a hermeneutic method based on linguistic analogies. The common term that connects the two festivals is "fifteenth." Just as one is obligated to eat (unleavened) bread on the fifteenth day of Nissan, so must one eat bread on the fifteenth of Tishre. Since the gezerah shavah is one of the thirteen hermeneutic rules, the resultant obligation can only be mi-divre sofrim according to Maimonides (as per his Rule 2). This understanding would readily explain Maimonides' use of the rabbinic term hovah to convey that night's obligation.

\section{The laws of sukkah}

The details of who must dwell in a sukkah and who is exempted from it, as well as all the physical details of the sukkah-its roof, walls, and

Periods, 239n1. 
materials - are dictated by tradition. Maimonides uses this series of laws in his introduction to the $P h M$, illustrating the authoritative role of oral law in the interpretation of written law and the inextricable relationship between the two. This analysis corroborates our suspicion that Maimonides considered the scriptural sukkah commandment to be a textual riddle. As he writes:

An example. God said to him [Moses]: Ye shall dwell in sukkot seven days. He, the exalted one, also informed him that the sukkah obligation is incumbent on males and not on females, and that the sick and the traveler are exempted from this obligation. One must roof the sukkah only with material that grows from the land; one may not roof it with wool, silk or utensils [kelim], even those that grow from the land, like mats and clothes. Eating, drinking and sleeping must take place in it all seven days. Its living space must not be smaller than seven by seven tefahim, and it must not be lower than ten tefahim.

The specifics of the laws of sukkah are thoroughly a construct of oral law. At best, the scriptural reference to sukkot is an asmakhta for the immensely complex set of rules that define all aspects of the sukkah's construction and the holiday's obligation.

I conclude that Maimonides lacked sufficient evidence to treat the laws of dwelling in a sukkah as a mitsvat'aseh de-oraita. From a peshateh diqera perspective, the obligation to dwell in a specially constructed booth for seven days did not seem to be scripturally commanded. Maimonides indicates this doubt through the use of a number of literary artifices, among them (but not limited to) the peculiar opening statement and the use of the participial form in which he couched the obligation.

\section{P169. LULAV}

In chapter 6, I noted the lack of a declarative statement in the commandment of taking the four species on Sukkot. I suggested that Maimonides may have thought it more appropriate to subsume this obligation under the commandment to rejoice on the festivals (P54). In other words, I treated his unusual presentation as a case of revised individuation. I also noted his use of a passive infinitive to describe the command to take the lulav: 
"mitsvat lulav [that is, the combination of the four species] is to be taken [le-hinatel] on the first day of the festival only-anywhere and at any time, even if this happens to be a Sabbath" (Hilkhot Lulav 7:13).

I now offer an alternative solution, based on the analysis of Maimonides' peshateh di-qera hermeneutics. The scriptural text does not specify the types of species (minim) that one must take on the festival of Sukkot. The verse "And ye shall take you on the first day the fruit of goodly trees, branches of palm trees, and boughs of thick trees, and willows of the brook" (Lev. 23:40) forms the basis of the commandment to take branches of a palm tree, a citron (etrog), branches of myrtle, and branches of willows of the brook. While tradition interprets the "fruit of goodly trees" and the "boughs of thick trees" as citrons and myrtle branches, respectively, the identification of these particular species cannot be derived from the text alone. ${ }^{44}$ Various midrashim attempt to justify the traditional identification of the four species, ${ }^{45}$ but, as Maimonides describes these midrashim, "they are not meant to bring out the meaning of the text in question." 46 Maimonides posits that taking these four species commemorates the "joy and gladness" that the Israelites felt when leaving the barren desert "for places in which there were fruit-bearing trees and rivers." He suggests that the choice of the four specific species was discretionary; the traditional interpretation satisfies a number of criteria, such as the availability of the species in the land of Israel, special fragrance, and guaranteed freshness for seven days. ${ }^{47}$

44. Translating peri ets hadar as the "boughs of majestic trees" allows the generalization of the three species that follow in the text and eliminates the notion of a single species. Similarly, anaf ets avot, the branches of a leafy tree, is also a non-specific category, difficult to reconcile with the myrtle. See Milgrom, Leviticus, 2065. In fact, the anaf ets avot and the leaves of the myrtle (hadas) are listed as two separate species in Nehemiah 8:15. See the comments of Ibn Ezra on Leviticus 23:40 and his defense of the rabbinic tradition against Karaite attacks.

45. See Maimonides' discussion of this point in his introduction to the Mishnah (Haqdamot ha-RaMBaM la-Mishnah, ed. Shailat, 38-39). Maimonides notes that while the identification of "fruit of goodly trees" with an etrog comes from the oral tradition, it is not considered a halakhah le-Moshe mi-Sinai, because hints in the verse allude to the etrog. See our discussion of halakhah le-Moshe mi-Sinai in chapter 7, note 10.

46. GP III:43: 573.

47. Ibid., 574. An element of practical discretion may also be detected in the words that Maimonides uses in Hilkhot Lulav 7:4 to support the identification of the four species: 
The laws of the four species parallel those of tefillin: observances for which the rabbis find creative but philologically untenable links between the underlying text and traditional practice. Because the peshateh diqera does not indicate particular species, Maimonides does not classify the commandments as scriptural. In this instance, however, because Maimonides does not use the participial form indicating customary practice, my conclusions are more tentative. Nevertheless, the rare passive infinitive form coupled with the lack of a declarative statement suggests that Maimonides is alerting the careful reader to a change in the commandment's classification: the taking of the four species is not, properly speaking, a mitsvat 'aseh de-oraita.

In this analysis, I have shown how Maimonides reclassified some of the most colorful and idiosyncratic practices of the Jewish faith from scriptural to non-scriptural status. This reclassification proceeds from the ultimate implications of Maimonides' hermeneutics of peshateh di-qera, which he dramatically postulates in the second Rule of the ShM. Certain subtle rhetorical hints signal this change: the lack of a declarative statement that the practice is a positive commandment; the absence of scriptural proof texts supporting the commandment; and the use of the participial form to describe the obligation.

To close this chapter, I offer a final point of clarification on the distinction between mitsvot de-oraita and mitsvot mi-divre sofrim. I noted above that Maimonides uses a participial form to indicate the level of obligation of several ostensibly scriptural commandments. Maimonides views these commandments as removed from the plain sense of Scripture; the practices associated with these commandments appear to originate in rabbinically-sanctioned customs and traditions, rooted in some unspecified past. By implication, these practices ought to be classified as mitsvot mi-divre sofrim instead of mitsvot de-oraita.

The very absurdity of such a proposition, which runs contrary both to centuries-old commonplace notions and to a substantial body of legal

"all these things [the identification of the four species] come down by tradition [mi-pi ha-shemuah] and were so explained [nitparshu] by Moses." This formulation deviates from the more usual "taught by tradition" [mi-pi ha-shemuah lamdu]. The difference between "taught" and "explained" may carry some significance. 
scholarship, throws doubt on such a radical proposition. For example, to call tefillin or sukkah a mitsvah mi-divre sofrim instead of a mitsvah deoraita would certainly be dismissed without any further consideration in any respected bet midrash. Yet this counterintuitive notion does seem to flow naturally from the peshateh di-qera doctrine of Rule 2. Moreover, in the Halakhot themselves, one finds support for the idea that commandments based on tradition, rabbinic interpretations, or analogic derivations from scriptural passages do not share the legal standing of explicit scriptural commandments, even if they impose the same practical sense of unconditional obligation as de-oraita commandments.

In chapter 7, I made brief reference to the ongoing controversy regarding the nature of mitsvot divre sofrim: should they be considered rabbinic both in origin and in force, or should they be considered rabbinic in origin but scriptural in force? Proponents for each of these views can be found among the most prominent medieval and modern scholars; the matter remains open. I have noted that I am not prepared to take a stand on this controversy. ${ }^{48}$ Nevertheless, I do not think that it is unrealistic to suggest that resistance to viewing mitsvot like tefillin as mitsvot mi-divre sofrim begins to diminish when one assumes that mitsvot mi-divre sofrim carry the force of mitsvot deoraita. Nevertheless, a larger question remains: if mitsvot mi-divre sofrim do carry the force of Torah law, why would Maimonides bother to make this distinction-even using the language of customary practice?

Following Hilkhot Mamrim 2:1, one might want to posit that a significant distinction between a mitsvah de-oraita and a mitsvah midivre sofrim is that only the latter type could be annulled by a court. On closer reading, however, one notes that Maimonides only applies this rule to laws derived hermeneutically through the thirteen principles, not to any mitsvah mi-divre sofrim. This legal distinction would not hold for cases of correct practices, since the latter appear to stem from traditions, perhaps halakhot mi-pi ha-qabbalah. Maimonides posits no mechanism for setting such types of laws aside.

The question stands: if these types of mitsvot mi-divre sofrim possess the same immutable characteristics as mitsvot de-oraita, what is the 
difference between these two categories? In what follows, I point to a small number of meaningful differences. A more thorough study may find additional examples.

In the treatise discussing transgressions incurred in error (Hilkhot Shegagot), Maimonides draws a distinction between scriptural laws explicitly found in the text and those that are not (though they still enjoy scriptural force). In the case of "the bullock offered for the unconscious transgression of the congregation," Maimonides rules that:

If the court erred and gave a ruling such as would uproot some main principle of the Law [gufmi-gufe torah], and all the people acted on their authority, the court are exempt and everyone who so acted is liable to a fixed sin offering ... The court never becomes liable unless they so rule as partly to annul and partly to sustain matters not explicit and plainly stated in the Law, whereupon the court becomes liable for the offering and they who act on their authority are not liable. (Hilkhot Shegagot 14:1-2, emphasis added)

Explicitly stated laws are laws that even the Sadducees, a prominent sectarian group who rejected the Oral Law, accepted; the Talmud (BT Horayot $4 \mathrm{~b}$ ) describes them as laws that any child would recognize. Erring with regard to such laws indicates forgetfulness rather than errors in judgment. Because the court was only liable for errors in judgment, they would not be liable for uprooting such laws.

In this analysis, Maimonides clearly distinguishes between explicitly formulated commandments and laws that derive their authority from tradition. The continuation of the halakhah makes this distinction clear: it contrasts carrying "a burden on the Sabbath from one domain to another" (an explicit scriptural law) with throwing or passing a burden from one domain to another (learned by tradition). Similarly, if the court uproots "one of the primary acts of work" on Shabbat, the court is liable because the laws relating to the primary acts of work are not stated explicitly in Scripture. Maimonides provides other examples of the distinct status of explicitly formulated laws in connection with the determination of the court's culpability when it has committed errors in judgment.

A similar distinction can be found in Hilkhot Biat ha-Miqdash 1:3, where Maimonides forbids an intoxicated individual from offering a legal decision unless the decision relates to "matters that are so explicit 
in the Torah that even the Sadducees know them." Once again, we see that explicitly stated laws, those recognizable by a fundamentalist literalist sect, enjoy a different standing than those not explicitly stated, which come under the heading of "teachings." The distinction between mitsvot de-oraita and mitsvot mi-divre sofrim that I am attempting to make would only work, of course, if we can assume that "teachings" are the functional equivalents of mitsvot mi-divre sofrim.

In this section, I have argued that in his rulings, Maimonides does consider explicitly-stated scriptural laws to be more authentically "scriptural" than the law derived from tradition, although I recognize that this pair of contrasting categories may not represent an exact parallel to the mitsvah de-oraita/mitsvah mi-divre sofrim pair. Moreover, I have assumed that the term "explicitly-stated" is equivalent to "the plain sense of Scripture," though I admit that "literal" might be a closer synonym. This distinction is evident in Hilkhot Shehitah 5:3, where Maimonides discusses the eight classes of trefot, animals unfit to eat, categorizing them as halakhot le-Moshe mi-Sinai. As we pointed out in chapter 7, laws of this type are considered by Maimonides to be mitsvot mi-divre sofrim. Crucially, Maimonides draws a legal distinction between the unfitness of the "torn" (derusah) animal and the seven other types of unfit animals, on the basis that the former is explicitly stipulated while the latter are only known by tradition. ${ }^{49}$

While I do not claim to have exhausted this complex subject, I believe that I have shown that there are meaningful differences between mitsvot de-oraita and mitsvot mi-divre sofrim, even on the assumption that the latter have the force of Torah law. Juristic precision would thus demand that Maimonides demarcate clearly between correct practices, or mitsvot mi-divre sofrim, and mitsvot de-oraita (in this case, mitsvot 'aseh).

We can only speculate as to why Maimonides qua legal theorist chose not to state explicitly that the given commandments were mitsvot mi-divre sofrim. One reason may be a fear of appearing to espouse

49. The distinction is applicable to punishments in the presence of a doubtful infringement of the prohibition to eat such trefot. For an interesting take on this matter, see the comments of Kelz, Maggid Mishneh, ad loc. 
heretical, Karaite views by prioritizing scriptural readings. A second, perhaps less likely reason may have to do with genuine doubts that he may have harbored about the full ramifications of his peshateh di-qera hermeneutics. Recall that in Rule 2, Maimonides eliminates derivations obtained via the thirteen rules of interpretation. We inferred from his discussion that all traditional interpretations, not just hermeneutic derivations, that do not stand textually on their own would also fall outside of the category of scriptural law. On this particular point, he may not have been all that certain. The use of the participial form would therefore reflect this ambivalent stance. With it, Maimonides neither acknowledges the commandment's scriptural status nor its non-scriptural one. He simply records the obligation without having to take a definitive stand. 